\title{
SENAM LANSIA MEMPENGARUHI TEKANAN DARAH LANSIA DI PUSKESMAS KEBONSARI SURABAYA
}

\author{
Diyah Pratiwi", Nety Mawarda Hatmanti ${ }^{* *}$ \\ Fakultas Ilmu Kesehatan UNUSA \\ E-mail: nety.mawarda@yahoo.com
}

\begin{abstract}
Hypertension is the most dominant disease whose cases are increasing to all over the world, happening especially to the elderly. The correct prevention and treatment can decrease Hypertension. One of the non-pharmacological treatments for Hypertension is the physical activity, such as the gymnastics for the elderly. The routine gymnastics will affect on the blood circulation, which will increase the function of heart so that the blood will be pumped to all over the body and finally decrease the blood pressure. The design of research was analytic-cross sectional.The population involved 63 elderly visiting Posyandu (Integrated Health Post) for the elderly in which 40 elderly were taken as the samples by using simple random sampling technique. The data were analyzed by using Chi-square statistic test with the significance level $\alpha=0,05$. The result of research showed the significant change on the blood pressure of the elderly who have actively done the gymnastics $(\rho<0,002)$. This research showed a relationship between the gymnastics for the elderly and the blood pressure of the elderly. In conclusion, the health workers at Puskesmas (Community Health Center) are expected to be more active in conducting the gymnastics for the elderly routinely so that they can get maximum result. Moreover, the community nurses should give information about benefits of gymnastics to the elderly so that they will get motivated to do it routinely.
\end{abstract}

\begin{abstract}
Abstrak : Hipertensi adalah penyakit paling dominan yang meningkat kasusnya di seluruh dunia, terutama pada usia lanjut usia. Pencegahan dan penanganan yang tepat dapat menurunkan hipertensi. Salah satu penanganan non farmakologi pada hipertensi adalah dengan kegiatan fisik seperti senam. Senam yang dilakukan secara rutin akan berdampak pada peredaran darah dan meningkatkan kerja jantung sehingga darah bisa dipompa dengan baik ke seluruh tubuh dan dapat menurunkan tekanan darah. Jenis penelitian ini adalah analitik dengan menggunakan pendekatan cross sectional. Populasi sebanyak 63 orang lansia yang datang di posyandu lansia. Sampel sebanyak 40 orang lansia yang diambil menggunakan tehnik simple random sampling. Data dianalisa dengan uji statistik chi-square dengan tingkat kemaknaannya adalah $\alpha=0,05$. Hasil penelitian menunjukkan bahwa perubahan yang signifikan dari tekanan darah pada lansia yang aktif melakukan senam lansia $(\rho<0,002)$. Penelitian ini menunjukkan bahwa ada hubungan senam lansia dengan tekanan darah pada lansia. Diharapkan kepada petugas kesehatan dari Puskesmas untuk lebih aktif dalam mengadakan kegiatan senam lansia secara rutin agar hasil yang diharapkan dapat dirasakan oleh lansia. Bagi perawat komunitas khususnya memberikan informasi tentang manfaat senam lansia sehingga lansia dapat termotivasi untuk melakukan hal ini secara rutin.
\end{abstract}

Kata kunci : senam lansia, tekanan darah. 


\section{PENDAHULUAN}

Menua merupakan proses menghilangnya secara perlahan kemampuan jaringan untuk memperbaiki diri atau mengganti diri dan mempertahankan struktur serta fungsi normalnya sehingga tidak dapat bertahan terhadap jejas (termasuk infeksi) dan memperbaiki kerusakan yang diderita (Darmojo B.R dan Martono H, 1994 dalam Wahjudi Nugroho, 2008). Hipertensi dapat terjadi dari berbagai faktor, diantaranya yaitu gaya hidup dan pola makan. Hipertensi juga dapat terjadi akibat obstruksi pada arteri dan kelemahan otot jantung untuk memompa darah. Hal itu disebabkan karena pada usia lanjut terjadi penurunan massa otot, kekuatan dari laju denyut jantung maksimal dan terjadinya peningkatan kapasitas lemak tubuh. Penyebab dari itu semua dapat dicegah dengan cara melakukan senam lansia secara teratur baik dari semasa muda hingga masa tua. Senam lansia yang dilakukan secara teratur dapat menanggulangi masalah akibat perubahan fungsi tubuh.

Hipertensi bisa menjadi awitan dari berbagai masalah kardiovaskuler lainnya yang lebih gawat. Menurut hasil Survei Kesehatan Rumah Tangga (SKRT) pada penderita hipertensi tahun 2011 yaitu sebanyak 29,3\% dan pada tahun 2012 sebanyak 36\%. Hal ini menyatakan prevalensi angka kejadian hipertensi semakin meningkat. Sekitar $80-90 \%$ tidak diketahui penyebabnya.

Berdasarkan studi pendahuluan yang telah dilakukan didapatkan data tingginya angka kejadian hipertensi di kota Surabaya terutama di Puskesmas Kebonsari pada tahun 2012 yaitu sebanyak 10.729 penderita. Hipertensi terutama diderita oleh lansia. Sedangkan data yang diambil dari salah satu Posyandu bahwa penderita hipertensi sebesar 13 orang $(4,8 \%)$ dari total jumlah lansia yang hadir sebanyak 63 orang. Puskesmas Kebonsari membawahi puluhan posyandu lansia, dari posyandu posyandu tersebut masih ada yang belum merealisasikan dilakukannya senam lansia. Padahal menurut teoritis aktivitas senam lansia dapat memberi pengaruh terhadap penurunan tekanan darah jika dilakukan secara teratur.

Pada tahun 2010 wadah senam lansia di Surabaya meningkat $18,1 \%$ yaitu sebanyak 137 lokasi sedangkan di tahun sebelumnya 116 lokasi. Pada kenyataannya banyak lansia yang kurang aktif atau kurang berpartisipasi dalam pemanfaatan senam lansia dikarenakan masih banyaknya lansia yang kurang mengetahui manfaat senam lansia (Anonymous, 2010). Menurut Green (1980) ada beberapa faktor yang menyebabkan lansia mengikuti senam antara lain : faktor predisposisi (pengetahuan, sikap, kepercayaan, keyakinan, usia, pekerjaan dan pendidikan), faktor pendukung (dana dan fasilitas kesehatan) dan faktor pendorong (petugas kesehatan) (Mubarak, 2007).

Penelitian yang dilakukan oleh Margiyati (2010) menunjukkan bahwa senam yang dilakukan oleh lansia dapat mempengaruhi penurunan tekanan darah pada lansia. Penelitian oleh Sukartini (2010) tentang manfaat senam terhadap kebugaran lansia yang menunjukkan bahwa senam dapat mempengaruhi tidak hanya stabilitas nadi, namun juga stabilitas tekanan darah sistolik dan diastolik, pernafasan dan kadar imunoglobin.

Dampak fisik maupun psikologis pada lansia yang menderita hipertensi adalah sering mengalami pusing, sakit kepala, tinnitus, penglihatan menjadi kabur dan jika sudah terlalu lama maka penderita kemungkinan akan mengalami depresi. Senam lansia secara teratur merupakan cara yang tepat untuk menurunkan tekanan darah pada lansia serta akan memberikan efek pergerakan pada seluruh otot muskuloskeletal agar tetap terbiasa melakukan gerakan (jangka panjang).

Dari pernyataan di atas maka peneliti tertarik melakukan penelitian tentang "Hubungan senam lansia dengan tekanan darah pada lansia di Posyandu Lansia wilayah kerja Puskesmas Kebonsari Surabaya" 


\section{METODE}

Dalam penelitian ini jenis yang digunakan adalah analitik dengan desain cross sectional. Populasi dalam penelitian ini adalah seluruh lansia yang datang di Posyandu Kebonsari Surabaya sebanyak 63 orang.

Jadi besar sampel yang digunakan dalam penelitian ini adalah 40 responden. Pengambilan sampel dilakukan secara probability sampling dengan tehnik simple random sampling. Variabel independen adalah senam lansia dan variabel dependen adalah tekanan darah. Instrumen yang digunakan untuk mengukur tekanan darah adalah spygmomanometer jarum dan stetoskop merek GEA, sedangkan instrumen kegiatan senam lansia adalah lembar observasi keaktifan lansia.

\section{HASIL DAN PEMBAHASAN}

\section{a. Hasil}

Hasil Data khusus berisi data tentang senam lansia, tekanan darah sebelum pelaksanaan senam lansia, tekanan darah setelah pelaksanaan senam lansia dan hubungan senam lansia dengan tekanan darah lansia sebelum dan sesudah mengikuti senam lansia.

1) Karakteristik mengikuti gerakan senam lansia

Tabel 1 Distribusi frekuensi responden menurut karakteristik mengikuti gerakan senam lansia di RW.01 Kelurahan Kebonsari Surabaya Maret 2013

\begin{tabular}{llll}
\hline No & $\begin{array}{l}\text { Karakteristik } \\
\text { mengikuti } \\
\text { gerakan } \\
\text { senam }\end{array}$ & Frekuensi & $\begin{array}{c}\text { Persentase } \\
(\%)\end{array}$ \\
\hline 1 & Benar & 26 & 65,0 \\
2 & Tidak benar & 14 & 35,0 \\
\hline Jumlah & 40 & 100 \\
\hline
\end{tabular}

Sumber: Data Primer, Maret 2013

Berdasarkan tabel 1 diatas menunjukkan bahwa dari 40 responden yang mengikuti gerakan senam, sebagian besar (65\%) memenuhi kriteria benar dalam mengikuti gerakan senam lansia.
2) Tekanan darah sebelum senam lansia

Tabel 2 Distribusi frekuensi responden menurut tekanan darah sebelum mengikuti senam lansia di RW 01 Kelurahan Kebonsari Surabaya Maret 2013.

\begin{tabular}{llll}
\hline No & $\begin{array}{l}\text { Tekanan } \\
\text { darah } \\
(\mathrm{mmHg})\end{array}$ & Frekuensi & $\begin{array}{l}\text { Persentase } \\
(\%)\end{array}$ \\
\hline 1 & $140-90$ & 29 & 72,5 \\
2 & $>140-90$ & 11 & 27,5 \\
\hline Jumlah & 40 & 100 \\
\hline
\end{tabular}

Sumber: Data Primer, Maret 2013

Berdasarkan tabel 2 diatas diketahui bahwa dari 40 responden, sebagian besar $(72,5 \%)$ memiliki klasifikasi tekanan darah $140 / 90 \mathrm{mmHg}$.

3) Hubungan senam lansia terhadap tekanan darah lansia sebelum dan sesudah mengikuti senam lansia

Tabel 3 Tabulasi silang hubungan senam lansia terhadap tekanan darah lansia di RW 01 Kelurahan Kebonsari Surabaya Maret 2013

\begin{tabular}{llccl}
\hline No. & $\begin{array}{c}\text { Senam } \\
\text { lansia }\end{array}$ & $\begin{array}{c}\text { Tekanan } \\
\text { darah } \\
\text { menurun } \\
\mathrm{n}(\%)\end{array}$ & $\begin{array}{c}\text { Tekanan } \\
\text { darah } \\
\text { tidak } \\
\text { menurun } \\
\mathrm{n}(\%)\end{array}$ & $\begin{array}{c}\text { Jumlah } \\
\mathrm{n}(\%)\end{array}$ \\
\hline $1 \quad$ Aktif & $22(84,6)$ & $4(15,4)$ & $\begin{array}{l}26 \\
(100)\end{array}$ \\
\hline 2 & $\begin{array}{l}\text { Tidak } \\
\text { aktif }\end{array}$ & $5(35,7)$ & $9(64,3)$ & $\begin{array}{l}14 \\
(100)\end{array}$ \\
\hline Jumlah & $27(67,5)$ & $\begin{array}{l}13 \\
(32,5)\end{array}$ & $\begin{array}{l}40 \\
(100)\end{array}$ \\
\hline
\end{tabular}

Sumber: Data Primer, Maret 2013

Berdasarkan tabel 3 dapat diketahui bahwa dari 26 responden yang melakukan gerakan senam lansia secara aktif hampir seluruhnya $(84,6 \%)$ mengalami penurunan tekanan darah setelah senam lansia, 14 responden yang tidak aktif dalam melakukan gerakan senam lansia sebagian besar $(64,3 \%)$ tidak mengalami penurunan tekanan darah setelah melakukan senam lansia.

Hasil uji statistik dengan menggunakan uji chi-square dengan tingkat kemaknaan $\alpha=$ 
0,05 dan dilakukan perhitungan SPSS didapatkan hasil $\rho=0,002$. Jika dibandingkan dengan $\alpha$, diperoleh $\rho(0,002)<\alpha(0,05)$ maka Ho ditolak berarti ada hubungan senam lansia dengan tekanan darah pada lansia di posyandu wilayah kerja Puskesmas Kebonsari Surabaya.

\section{b. Pembahasan}

\section{1) Senam Lansia}

Dari hasil penelitian, dari 40 responden dalam penelitian ini sebagian besar responden yang mengikuti senam lansia secara aktif yaitu sebanyak 26 responden (65\%).

Senam lansia membuat denyut jantung meningkat dalam periode waktu yang lebar. Pada saat denyut jantung meningkat, hal ini berarti suplai atau aliran darah ke seluruh bagian tubuh bertambah banyak, tersedianya oksigen yang cukup untuk kebutuhan jaringan dan sel tubuh. Senam yang dilakukan secara teratur sangat penting bagi tubuh dalam menjaga kesehatan jantung. Hal ini sesuai dengan teori aktivitas (Stanley, Beare, 2006) yang berpendapat bahwa jalan menuju penuaan yang sukses adalah dengan cara tetap aktif. Pentingnya aktivitas mental dan fisik seperti olahraga (senam) yang berkesinambungan dapat mencegah kehilangan dan pemeliharaan kesehatan sepanjang masa kehidupan manusia.

Dari hasil penelitian menunjukkan bahwa dari 26 responden sebagian kecil $(15,4 \%)$ yang benar dalam mengikuti senam lansia ternyata setelah diukur kembali tekanan darahnya tidak mengalami penurunan.

Menurut pendapat Green (1980) yang dikutip oleh Mubarak (2007), ada beberapa faktor yang menyebabkan keaktifan lansia dalam mengikuti senam antara lain : faktor predisposisi (pengetahuan, sikap, kepercayaan, keyakinan, umur, pekerjaan dan pendidikan), faktor pendukung (dana dan fasilitas kesehatan) dan faktor pendorong (petugas kesehatan)

Pada usia lanjut, manusia akan mengalami kemunduran organ-organ tubuh. Maka dengan mengikuti senam lansia dapat menghambat proses tersebut dan dapat menjaga prestasi yang dimiliki. Menurut Kusuma (2006), senam adalah suatu olahraga yang mampu meningkatkan aliran darah, meningkatkan kelenturan sendi dan melatih dalam pengaturan nafas. Oleh karena itu olahraga atau senam perlu diperhatikan dan dilakukan secara teratur sehingga meskipun sudah lanjut usia tetap selalu bahagia dan berdaya guna dengan keadaan yang dihadapinya

\section{2) Tekanan Darah}

Berdasarkan hasil penelitian dijelaskan bahwa dari 40 responden seluruhnya (100\%) mempunyai tekanan darah tinggi (hipertensi) dengan kriteria hipertensi (140/90) $\mathrm{mmHg}$ sebanyak 29 responden $(72,5 \%)$ dan kriteria hipertensi stadium 1 (> 140-90) $\mathrm{mmHg}$ sebanyak 11 responden $(27,5 \%)$.

Menurut pendapat Sutanto (2010) bahwa dengan bertambahnya usia, kemungkinan seseorang menderita hipertensi juga semakin besar. Hilangnya elastisitas jaringan dan arterosklerosis serta pelebaran pembuluh darah adalah faktor penyebab hipertensi pada usia tua.

Berdasarkan pendapat Astawan (2005) hipertensi umumnya terjadi karena ACE (Angiotensin Converting Enzyme) memegang peranan penting dalam mengatur tekanan darah. ACE yang terdapat di paru-paru diubah menjadi angiotensin tipe II yang dalam peranan menaikkan tekanan darah melalui dua aksi utama yaitu dengan meningkatkan sekresi ADH sehingga urin yang keluar sedikit dan menjadi pekat. Dalam proses pengenceran osmolalitasnya diperlukan volume cairan ekstraseluler yang diambil dari bagian intraseluler akibatnya volume darah meningkat yang pada akhirnya akan meningkatkan tekanan darah. Aksi yang lain yaitu dengan menstimulasi sekresi aldosteron yang berfungsi untuk mengatur ekstraseluler sehingga akan mengurangi sekresi $\mathrm{NaCl}$ dan untuk mengencerkan kembali $\mathrm{NaCl}$ untuk diabsorbsi kembali dengan meningkatkan volume cairan ekstraseluler yang pada gilirannya akan meningkatkan volume dan tekanan darah. 
3) Hubungan Senam Lansia dengan Tekanan Darah pada Lansia

Hasil penelitian menunjukkan dari 26 responden yang aktif melakukan senam lansia hampir seluruhnya $(84,6 \%)$ mengalami penurunan tekanan darah setelah melakukan senam lansia. Berdasarkan analisis data menggunakan uji chi-square, tingkat kemaknaannya adalah $\alpha=0,05$. Hasil perhitungan statistik uji chi-square didapatkan nilai $\rho=(0,002)$. Jika diabndingkan dengan $\alpha$, diperoleh $\rho(0,002)<\alpha(0,05)$ maka Ho ditolak artinya ada hubungan senam lansia dengan tekanan darah di Puskesmas Kebonsari Surabaya. Hal ini sesuai dengan penelitian Sukartini (2010) tentang manfaat senam terhadap kebugaran lansia yang menunjukkan bahwa senam dapat mempengaruhi tidak hanya stabilitas nadi, namun juga stabilitas tekanan darah sistolik dan diastolik, pernafasan dan kadar imunoglobulin.

\section{SIMPULAN}

a. Lansia di Posyandu Wilayah Kerja Puskesmas Kebonsari Surabaya sebagian besar mempunyai gerakan senam lansia benar.

b. Lansia di Posyandu Wilayah Kerja Puskesmas Kebonsari Surabaya hampir seluruhnya mengalami penurunan tekanan darah.

c. Ada hubungan senam lansia dengan tekanan darah pada lansia di Posyandu wilayah kerja Puskesmas Kebonsari Surabaya.

\section{DAFTAR RUJUKAN}

Arikunto, S. (2010). Prosedur Penelitian. Jakarta : Rineka Cipta

Astawan, Made. (2005). Cegah Hipertensi dengan Pola Makan. http://www.depkes.com. Diakses tanggal 3 Januari 2012 jam 10.00 WIB

Audah, Faiza. (2011). Dahsyatnya Tehnik Pernafasan. Yogyakarta : InterPreBook
Azizah M.L. (2011). Keperawatan Lanjut Usia. Yogyakarta : Graha Ilmu

Corwin, J. Elizabeth. (2004). Buku Saku Patofosiologi. Jakarta : EGC

Dalimartha, Setiawan (2008). Care your Self, Hipertensi. Jakarta : Penebar plus+

Depkes. (2009). Hipertensi pada Lansia. Diakses dari www.depkes.go.id pada tanggal 23 Januari 2013

Karya, Teguh (2012). Sport education, Health, Injuries, Coaching and Organization. http://teguhkarya277.blogspot.com.

Diakses tanggal 17 April 2013 pukul 17.00 WIB

Koswara, S. (2003). Menu Sehat bagi Manula. http://www.ebookpangan.com. Diakses pada tanggal 23 Januari 2013 pukul 17.00 WIB

Kusmana, D.(2006). Olahraga untuk Orang Sehat \& Penderita Penyakit Jantung. Jakarta : Balai Penerbit Fakultas Kesehatan Universitas Indonesia

Marks (2011). Relaksasi Otot Progresif dengan pemenuhan Kebutuhan Tidur Lansia. Jurnal USU, Diakses tanggal 22 Januari 2013 pukul 11.00 WIB

Maryam, R. Siti. Et al. (2008). Mengenal Usia Lanjut dan Perawatannya. Jakarta, Salemba Medika

Mutaqqin, Arif. (2009). Asuhan Keperawatan dengan pasien Gangguan Kardiovaskuler. Jakarta : Salemba Medika

Notoatmodjo, Soekidjo (2010). Metodologi Penelitian Kesehatan. Jakarta : Rineka Cipta 
Nugroho, Wahjudi. (2008). Keperawatan Gerontik dan Geriatri. Edisi 3. Jakarta : EGC

Nursalam (2011). Konsep dan Penerapan Metodologi Penelitian Ilmu Keperawatan Pedoman Skripsi, Tesis dan Instrumen Penelitian Keperawatan.. Edisi 2. Jakarta : Salemba Medika

Stanley, Mickey dan Beare, Patricia Gauntlett. (2007).. Buku Ajar Keperawatan Gerontik. Edisi 2. Jakarta : EGC

Suiraoka, IP. (2012). Penyakit Degeneratif mengenal, mencegah dan mengurangi faktor resiko 9 penyakit degeneratif. Yogyakarta : Nuha Medika

Sumintarsih. (2006). Kebugaran Jasmani untuk Lansia.. Olagraga, 147-160

Suroto, (2004). Buku Pegangan Kuliah Pengertian Senam, Manfaat Senam dan urutan Gerakan. Semarang : Unit pelaksana Teknis Mata Kuliah Umum Olahraga Undip 